\title{
LITERACY EDUCATION URGENCY FOR CENTENNIAL GENERATION IN INDUSTRIAL REVOLUTION 4.0
}

\author{
Muhamad Yusuf \\ Institut Agama Islam Negeri Kerinci \\ Mira Zuzana \\ Madrasah Aliyah Negeri 1 Kerinci \\ Doli Witro \\ UIN Sunan Gunung Djati Bandung
}

\section{Abstract}

When talking about children's abilities, they indeed cannot be separated from their educational or training background. Moreover, he has entered the working age that must have productivity in his work, especially at this time, where the era has entered the industrial revolution 4.0. The industrial revolution 4.0 is marked by the development of digitalization in various lines of life. On the one hand, the industrial revolution 4.0 had many positive impacts. However, on the other hand, as the McKinsey Global Institute states that as a result of the 4.0 industrial revolution in the next five years, there will be 52.6 million jobs that will decline and even disappear. This certainly will be a challenge for the centennial generation (children born from 1996-2011) at this time, which they have to survive with the existing conditions and situations. This paper will discuss several factors that describe and address issues such as what is meant by the centennial generation, literacy, and the urgency of literacy education for the centennial generation in the digital age. According to authors, thi is essential to discuss, given the increasingly rapid development and technological progress resulting in the loss of much work.

Keywords: Literacy, Centennial Generation, Industrial Revolution 4.0

\section{Abstrak}

Ketika berbicara mengenai kemampuan anak tentunya tidak bisa lepas dari latar belakang pendidikan ataupun pelatihan yang pernah ia ikuti. Terlebih lagi ia sudah memasuki usia kerja yang harus memiliki produktivitas dalam pekerjaannya. Apalagi pada masa sekarang ini, di mana zaman telah memasuki revolusi industri 4.0. Revolusi industri 4.0 ditandai dengan berkembangnya digitalisasi di berbagai lini kehidupan. Di satu sisi revolusi industri 4.0 memberikan banyak dampak positif. Namun, di sisi lain, sebagaimana McKinsey 
Global Institute menyatakan akibat revolusi industri 4.0 dalam lima tahun ke depan akan ada 52,6 juta macam pekerjaan akan mengalami kemunduran bahkan hilang keberadaannya. Hal ini tentunya akan menjadi tantangan bagi generasi centennial (baca: anak kelahiran 1996-2011) saat ini, yang mana mereka harus bertahan dengan kondisi dan situasi yang ada. Tulisan ini akan membahas mengenai beberapa anasir yang menggambarkan dan menjawab persoalan seperti apa yang dimaksud dengan generasi centennial, literasi, serta urgensi pendidikan literasi bagi generasi centennial di era digital. Menurut penulis, hal ini penting untuk dibahas, mengingat perkembangan dan kemajuan teknologi semakin pesat yang mengakibatkan hilangnya banyak pekerjaan.

Kata Kunci: Literasi, Generasi Centennial, Revolusi Industri 4.0

\section{INTRODUCTION}

When talking about children's abilities, they indeed cannot be separated from their educational or training background. Moreover, he has entered the working age that must have productivity in his work. One of the clear examples can be seen from experience "Frederick Winslow Taylor in 1870 began his career as a worker in a small workshop in Philadelphia. In 1895 Taylor organized an 'A Piece Rate System' seminar in the American mechanic's community. In 1903 the results of his seminar were posted with the title 'Shop Management'. Taylor's research proves that trained coal miners have an average productivity increase of over $100 \%$ compared to those not given education or training". ${ }^{1}$ Frederick's research results above show that education or training determines a person's work productivity. Especially at this time, where the era has entered the industrial revolution.

Experts say that at this time, the world has entered the industrial revolution 4.0. The industrial revolution 4.0 is marked by the development of digitalization in various lines of life. For

${ }^{1}$ Siswoyo Hariyono, "Re-orintasi Pengembangan SDM Era Digital Pada Revolusi Industri 4.0", Makalah, disampaikan dalam The National Conference on Management and Business (NCMAB) 2018, Universitas Muhammadiyah Surakarta pada 5 Mei 2018, p. 5. 
example, online transportation such as Go-Jek and Grab. Both companies utilize technology in the digital age to increase the economic growth of the community. Besides, can see the convenience provided by online shopping sites such as Shopee and Tokopedia. ${ }^{2}$

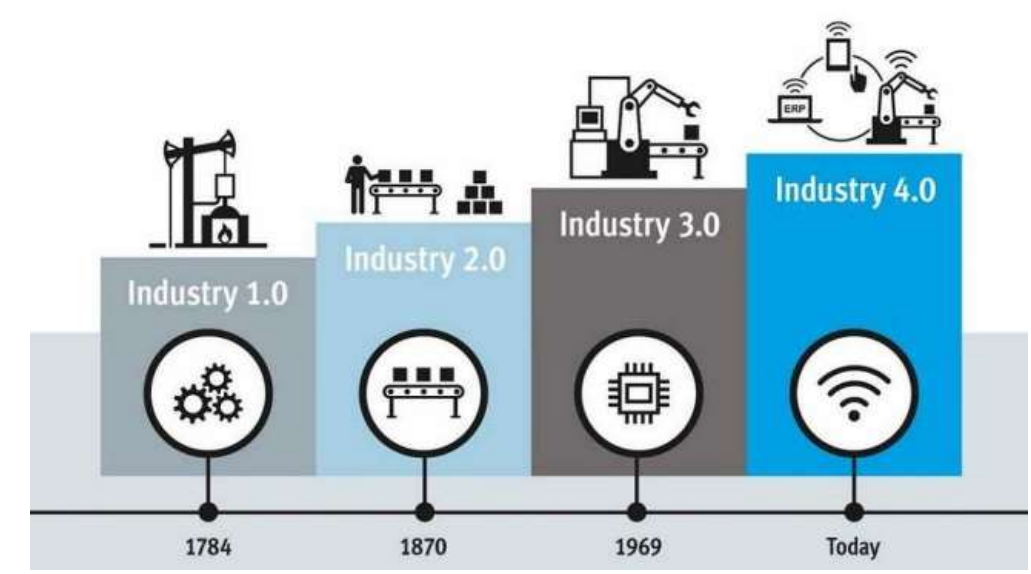

Picture 1. Illustration of the Industrial Revolution 4.0. Source: myrahmattriandisetiawan.blogspot.com (4/6/2018).

All the examples above are the positive side of the development of the industrial revolution 4.0. However, if look at the other side, which is the International Research Institute, McKinsey Global Institute stated in the results of research conducted in 2016 that due to the 4.0 industrial revolution in the next five years, there will be 52,6 million types of jobs will decline and even disappear. ${ }^{3}$ This certainly will be a challenge for the centennial generation (read: children) at this time, which they have to survive with the existing conditions and situations.

2 Mhd. Rasidin, Imaro Sidqi, and Doli Witro, "Drop Shipping in Islamic Economic Law Perspective: E-Commerce Study Inter Marketplace Drop Ship in the Industrial Revolution Era 4.0", Nurani, Vol. 20, No. 1, 2020, p. 97 and 101.

3 Hendra Suwardana, "Revolusi Industri 4.0 Berbasis Revolusi Mental", Jati Unik, Vol. 1, No. 2, 2017, p. 103. 
This paper will discuss some of the factors that describe and answer issues such as what is meant by the centennial generation and literacy and how the urgency of literacy education for the centennial generation in the digital age. According to the author essential to discuss, given the development and advancement in technology (read: industrial revolution 4.0), which is causing the rapid loss of many jobs. With the existence of literacy education, it is expected that the centennial generation will be able to adjust to the times, moreover can use technology and information to create jobs.

\section{DISCUSSION}

The term centennial generation is indeed not too familiar to sound. According to Manheim, generation is a social construction in which there is a group of people who have the same age and historical experience. Manheim further explained that individuals who are part of one generation have the same birth year in 20 years and are in the same social and historical dimensions. This definition was developed explicitly by Ryder, who said that generation is an aggregate of individuals who experience the same events in the same period. In recent years the definition of generation has developed, one of which is the definition according to Kupperschmidt's which says that a generation is a group of individuals who identify their group based on the same birth year, age, location, and events in the life of that individual group that has a significant influence in the growth phase they. ${ }^{4}$

However, this term exists along with the existence of the millennial generation. A millennial generation, or in other terms referred to as generation $\mathrm{Y}$ is the generation whose birth ranged from 1980 to 1995 . However, it is different from the centennial generation or known as generation $Z$ is the generation whose birth ranged from 1996 to 2011. This generation can be called very familiar with digital technology.

4 Yanuar Surya Putra, "Theoritical Review: Teori Perbedaan Generasi”, Among Makarti, Vol. 9, No. 18, 2016, h. 124. 
This is because they were born in the digital age and have also been familiar with digital technology from birth. So it is no exaggeration to say that the centennial generation is a subject that will run digital technology. ${ }^{5}$

Centennial generation has similarities with the millennial generation, which is the generation who are equally literate towards technology. However, in addition to the similarities, these two generations also have differences in their application. Centennial generation is capable and accustomed to carrying out activities related to digital technology at one time (multi-tasking) minutes, using social media ${ }^{6}$ with cellphones, browsing using a computer, and listening to music using a headset. ${ }^{7}$

Generation $\mathrm{Z}$ is the generation of information, and all information limitations have to open widely through social media and the internet. Online source is a terminology most important in information search, and vice versa print media is the least used by generation $Z$ in seeking information. Generation $Z$ is the most imaginative generation and has a lifestyle that can never be separated from the internet. According to Luntung et al., There are five critical characters possessed by Generation Z, one of which is the generation of social media. Generation $Z$ is also known as iGeneration, Net Generation, or Internet Generation, which is the generation that lives in the digital era. Generation $\mathrm{Z}$ is also referred to as

${ }^{5}$ Kartini, Democracy of Centennial, Wadah Ide Kreatif Generasi Z, (Online), (http://majalahkartini.co.id/, accessed 26 Desember 2019).

6 Social media is an internet-based media that allows users the opportunity to interact and present themselves, both instantaneously and delayed, with a broad audience or not that encourages the value of usergenerated content and the perception of interaction with others. See, Doli Witro, Luqyana Azmiya Putri, and Vegia Oviensy, "Kontribusi Media Sosial Terhadap Produktivitas Karyawan Generasi Milenial PT Perkebunan Nusantara VI Kayu Aro”, Jurnal Ekonomi \& Bisnis, Vol. 18, No. 2, 2019, p. 119.

7 Yanuar Surya Putra, "Theoritical Review: Teori Perbedaan Generasi..., p. 130. 
"the future digital natives," a young generation that grows and develops with a large dependence on digital technology. ${ }^{8}$

If look at the age range of the centennial generation between 1996 and 2011, it can be said that the centennial generation is someone who is still a child. ${ }^{9}$ This is similar to what was mentioned in The Minimum Age Convention Number. 138 of 1973 that, a child is someone who is not yet 15 years old or under. It was also mentioned in the Convention on the Right of the Child in 1989, which had been ratified by the Indonesian government with Presidential Decree Number 39 of 1990 that, children are those who are 18 years old and under. UNICEF defines a child as someone who is between 0 and 18 years old. RI Law Number 4 of 1979 concerning Child Welfare, states that children are those who are not yet 21 years old and not married. Whereas the Marriage Law stipulates an age limit of 16 years. ${ }^{10}$ Departing from the above understanding, the centennial generation is the nation's generation, which must obtain an education so that it can be useful for the nation and state. In this case, the centennial generation is not only a subject for change but also as an object that must have the literacy ability to face the development of the industrial revolution 4.0.

According to the National Association for Media Literacy Education (NAMLE), literacy is a communication competency in which there are several kinds of abilities that a person has, for example, accessing, analyzing, evaluating, and communicating

8 Giovani Santoso and Anna Triwijayati, "Gaya Pengambilan Keputusan Pembelian Pakaian Secara Online pada Generasi Z Indonesia”, Jurnal Ilmu Keluarga dan Konsumen, Vol. 11, No. 3, 2018, p. 233.

${ }^{9}$ When you want to plant a knowledge of someone, then at the age of the children are the best. One way is by habituation. See, Doli Witro, “ Islamic Religious Education in the Family to Strengthen National Resilience of Surah At-Tahrim Verse 6 Perspective", Al-Muaddib :Jurnal Ilmu-Ilmu Sosial dan Keislaman, Vol. 4, No. 2, 2019, p. 313.

10 Yustikasari dan Lukiati Komala, "Literasi Media pada Anak (Studi tentang Literasi Media pada Anak dalam Membangun Pemahaman tentang Penggunaan Media)", Seminar Nasional Bahasa, Sastra, dan Budaya, Vol. 1, No. 1, 2017, p. 460. 
information between one another, obtained from print media and media electronic. ${ }^{11}$ From the understanding of literacy above, there are at least three things that need to be considered to have the most basic literacy abilities. First, the ability to access messages, namely accessing messages contained in the media, both print and electronic media; Second, analyzing messages means researching, understanding messages received from the media; and third, evaluating messages that have been accessed and analyzed. At this stage, the child must be able to provide an assessment of the message received according to the facts and avoid hoaxes (fake news). ${ }^{12}$

In the digital age, children inevitably have to adapt to the times. Who is not able to adapt, then he will be eliminated. Parents are the first and foremost educators ${ }^{13}$ in teaching literacy to children because before children take formal education in school, children first get an education from parents. Parents have a significant role in helping children to get functional literacy in school. ${ }^{14}$

11 Sri Sukasih, dkk, "Literasi Media Berbasis Pendidikan Karakter bagi Mahasiswa PGSD Unnes", Jurnal Penelitian Pendidikan, Vol. 32, No. 2, 2015, p. 163-164.

12 The child's assessment of the message received is a form of clarification so that he can be avoided from hoaxes. See, Doli Witro, "Urgency Rijalul Posting in Preventing Hoax: Quranic Perspective", Islamic Communication Journal, Vol. 5, No. 1, 2020, p. 45. See too, Doli Witro, "Problematika Hoax di Media Sosial: Telaah Pesan Tabayyun dalam Surat Al-Hujurat/49: 6", Proceedings of the 3rd BUAF (Borneo Undergraduate Academic Forum), Institut Agama Islam Negeri (IAIN) Palangkaraya, Kalimantan Tengah, Indonesia, 17-19 Oktober 2018, p. 188.

${ }^{13}$ Muhamad Yusuf, Doli Witro, Rahmi Diana, Tomi Apra Santosa, Annisa 'Alwiyah Alfikri, and Jalwis, "Digital Parenting to Children Using the Internet". Pedagogik Journal of Islamic Elementary School, Vol. 3, No. 1, 2020, p. 9. See too, Doli Witro, Berlian Arista Putri, Luqyana Azmiya Putri, and Vegia Oviensy, "Role of the Family in Formation of Children Characters Based Moral Knowing, Moral Feeling, and Moral Action", Tunas Cendekia: Jurnal Program Studi Pendidikan Islam Anak Usia Dini, Vol. 3, No. 1, 2020.

14 Yessy Gusminalita, Doli Witro, and Kesi Afrilia, "Education Child in a Family of Surah An-Nisa' Verse 9 Perspective", Pionir: Jurnal Pendidikan, Vol. 9, No. 1, 2020, p. 17. 


\section{The Urgency of Literacy Education For Centennial Generations In The Digital Era}

Central Bureau of Statistics (BPS), In 2018, the unemployment rate in Indonesia was $5.34 \%$, equal to 6.99 million of the total 131.01 million workforces. ${ }^{15}$ The high unemployment rate is one of the reasons, namely the inability of a person to adjust to the times. For example, in the past, the post office was only known for sending letters. With vast distances, it can take weeks or even months. However, now there is an electronic mail called e-mail, just wait a few minutes, the letter sent can be directly received even with a great distance. Besides, there is also introduced with a video call -a voice and picture call that can see directly the user who receives a call-. There is much personal work that has been replaced by machines in the 4.0 industrial revolution. That is why it is said that the centennial generation must adapt to the times.

\begin{tabular}{|c|c|c|c|c|c|c|}
\hline \multirow{2}{*}{$\begin{array}{l}\text { GDP PPP } \\
\text { rankings }\end{array}$} & \multicolumn{2}{|c|}{2016 rankings } & \multicolumn{2}{|c|}{2030 rankings } & \multicolumn{2}{|c|}{2050 rankings } \\
\hline & Country & GOP atPPP & Country & $\begin{array}{l}\text { Projected } \\
\text { GDP at PPP }\end{array}$ & County & $\begin{array}{l}\text { Projected } \\
\text { GDP at PPP }\end{array}$ \\
\hline 1 & China & 21269 & China & 38008 & China & 58499 \\
\hline 2 & United States & 18562 & United States & 23475 & India & 44128 \\
\hline 3 & India & 8721 & Inda & 19511 & United States & 34102 \\
\hline 4 & Japan & 4932 & Japan & 5606 & Indonesia & 10502 \\
\hline 5 & Germany & 3979 & Indonesia & 5424 & Brazil & 7540 \\
\hline 6 & Russia & 3745 & Russia & 4736 & Russia & 7131 \\
\hline 7 & Brazil & 3135 & Germany & 4707 & Mexico & 6863 \\
\hline 8 & Indonesia & 3028 & Brazl & 4439 & Japan & 6779 \\
\hline 9 & United Kingoom & 2788 & Mexico & 3661 & Germany & 6138 \\
\hline 10 & France & 2737 & United Kingdom & 3638 & United Kingdom & 5369 \\
\hline
\end{tabular}

Picture 3. Projection Calculation Gross Domestic Product $(G D P)^{16}$. Size Number Using US\$ Billion.

15 Badan Pusat Statistik, Agustus 2018: Tingkat Pengangguran Terbuka (TPT) Sebesar 5,34 Persen, (Online), (https://www.bps.go.id/, accessed 26 Desember 2019).

16 Gross Domestic Product (GDP) can be defined as the value of final goods and services produced by various production units in the territory of a country within a year. See, Andra, Pengertian Gross Domestic Product 
Source: www.pwc.com (9/2/2017).

The Audit Institute and Economic Consultant, PricewaterhouseCoopers (PWC) predicted that Indonesia would become the 5th largest economy in the world by 2030 and become the 4th largest economy in the world by 2050. ${ }^{17}$ This means that this institution has seen from now on that Indonesia has great potential. One of the reasons why Indonesia is one of the largest economies in the world is because of its productive age at the time. In 2030-2050 the productive age of Indonesia is very much so that it is expected to become the cornerstone of economic growth.

This prediction can be right if the productive age in question can act as an economic driver. One aspect that must support this productive age is education. However, if the opposite happens, this productive age of education is not right. Precisely this will become a burden for the country. Even the unemployment rate will increase.

This certainly can be a whip of motivation for the centennial generation today. Because in 2030-2050, it is they who determine whether this nation is good or not. They are what is meant by productive age in 2030-2050. However, ironically "Indonesia is currently ranked 87th out of 157 countries in the Human Capital Index in 2018 issued by the World Bank". ${ }^{18}$ This statement shows that the quality of Indonesia's human resources is still low. Therefore, to become one of the countries with the largest economy in the world is very far away. However, that does not mean it is not possible to

(GDP) atau Produk Domestik Bruto (PDB), (Online), (https://ardra.biz/, accessed 26 Desember 2019).

17 Dkatadata, PWC: 2030, Ekonomi Indonesia Terbesar Ke-5 di Dunia, (Online), (https://databoks.katadata.co.id/, accessed 26 Desember 2019). See also, PwC Indonesia, PwC: Indonesia Akan Menjadi Negara Dengan Perekonomian Terbesar Ke-4 di 2050, (Online), (https://www.pwc.com/, accessed 26 Desember 2019).

18 Tirto.id, Indeks SDM Bank Dunia 2018: Singapura Peringkat 1, Indonesia Ke-87, (Online), (https://tirto.id/, accessed 26 Desember 2019). 
improve the quality of existing human resources with education in the current 4.0 industrial revolution era.

One of the educational needs of the centennial generation is literacy education. However, literacy education is not taught in formal schools, which can be obtained like other education. Literacy education is needed to adjust to the industrial revolution 4.0. Therefore, to face challenges in the era of the industrial revolution 4.0, it is not enough to only have old human literacy, which is only based on the ability to read, write, and count.

According to Aoun, to create human resources capable of competing in the competition in the 4.0 industrial revolution, the educational curriculum implemented in the output schools must be able to master new literacy, namely: (1) data literacy, namely the ability to read, analyze and utilize the big data contained in cyberspace; (2) technological literacy, which is an understanding of how machines work and the application of technology (coding, artificial intelligence, and engineering principles); (3) human literacy, namely humanities, communication, and design. ${ }^{19}$ The centennial generation must control the third literacy.

In 1990, there was a famous phrase, "who controls data and information, he will rule the world". This sentence in the industrial revolution 4.0 might be said to be no longer relevant because many data must be processed. Then it must be accompanied by the ability to understand the workings of machines and human literacy. In human literacy, children must be able to read, understand the fun of many people. Because the market or scope of the industrial revolution 4.0 is the world. Until now, the role of the government has been seen in developing the quality of human resources to be able to adjust to the industrial revolution era 4.0. For example, Co-Working Space on student extracurricular activities.

Co-Working Space is a new workspace where users work with other people from different companies or organizations in

${ }^{19}$ Siswoyo Hariyono, "Re-orintasi Pengembangan SDM..., p. 12. 
one place. Co-Working Space is a space that can be used to work, produce work collaboratively both between individuals and companies who have different business backgrounds. ${ }^{20}$ However, so far, it cannot be said to be useful because it is still extracurricular. Something extracurricular is limited. This means that not everyone can choose and take and participate in these activities because there is no requirement for tertiary education for all students.

It is different from the education curriculum, which must be achieved by tertiary institutions and is required of all students. For example, conducted by Finland, as reported by the World's Most Literate Nations (WMLN) in 2016, Finland is the country with the best literacy level in the world. In Finland, primary education or what is known in comprehensive schools has an essential role in instilling literacy culture in students. Primary education starts at the age of 7 years until the age of 15 years. ${ }^{21}$ This means that literacy education in Finland has been taught from the beginning to take formal education. This indeed can be said that literacy education is included in the country's national education curriculum.

\section{CONCLUSION}

Based on the description above, it can be understood literacy education is education that teaches the ability to access, analyze, evaluate, and communicate information with one another, obtained from print media and electronic media. In the industrial revolution 4.0, a child must not only have old human abilities such as reading, writing, and counting. However, it must also have new literacy, namely data literacy, technological literacy, and human literacy. Therefore according

20 Voffice, Pengertian Co-Working Space, (Online), (http://voffice.co.id/, accessed 26 Desember 2019). See also, Tirto.id, CoWorking Space Bukan Sekadar Tempat Kerja, (Online), (https://tirto.id/, accessed 26 Desember 2019).

21 Jawapos.com, Rahasia Budaya Literasi Finlandia, Bayi Lahir Dapat Paket Berisi Buku, (Online), (https://www.jawapos.com/, accessed 26 Desember 2019). 
to the opinion of the writer, it would be nice if this literacy education is included in the national education curriculum in Indonesia so that every student can have literacy abilities -data literacy, technological literacy, and personal literacy-. With the literacy ability possessed by each student is expected to become a provision to adjust and be able to take advantage of big data in the industrial revolution 4.0. Moreover, it can improve the quality of Indonesian human resources.

\section{REFERENCES}

Andra, Pengertian Gross Domestic Product (GDP) atau Produk Domestik Bruto (PDB), (Online), (https://ardra.biz/, accessed 26 Desember 2019).

Badan Pusat Statistik, Agustus 2018: Tingkat Pengangguran Terbuka (TPT) Sebesar 5,34 Persen, (Online), (https://www.bps.go.id/, accessed 26 Desember 2019).

Dkatadata, PWC: 2030, Ekonomi Indonesia Terbesar Ke-5 di Dunia, (Online), (https://databoks.katadata.co.id/, accessed 26 Desember 2019).

Gusminalita, Yessy, Doli Witro, and Kesi Afrilia, 2020, "Education Child in a Family of Surah An-Nisa' Verse 9 Perspective", Pionir: Jurnal Pendidikan, Vol. 9, No. 1.

Hariyono, Siswoyo. 2018. "Re-orintasi Pengembangan SDM Era Digital Pada Revolusi Industri 4.0". Makalah, disampaikan dalam The National Conference on Management and Business (NCMAB) 2018, Universitas Muhammadiyah Surakarta.

Jawapos.com, Rahasia Budaya Literasi Finlandia, Bayi Lahir Dapat Paket Berisi Buku, (Online), (https://www.jawapos.com/, accessed 26 Desember 2019).

Kartini, Democracy of Centennial, Wadah Ide Kreatif Generasi Z, (Online), (http://majalahkartini.co.id/, accessed 26 December 2019 2019). 
Putra, Yanuar Surya. 2016. "Theoritical Review: Teori Perbedaan Generasi". Jurnal IImiah Among Makarti, Vol. 9, No. 18.

PwC Indonesia, PwC: Indonesia Akan Menjadi Negara Dengan Perekonomian Terbesar Ke-4 di 2050, (Online), (https://www.pwc.com/, accessed 26 Desember 2019).

Rasidin, Mhd., Imaro Sidqi, and Doli Witro, 2020, "Drop Shipping in Islamic Economic Law Perspective: ECommerce Study Inter Marketplace Drop Ship in the Industrial Revolution Era 4.0", Nurani, Vol. 20, No. 1.

Santoso, Giovani and Anna Triwijayati, 2018, "Gaya Pengambilan Keputusan Pembelian Pakaian Secara Online pada Generasi Z Indonesia", Jurnal IImu Keluarga dan Konsumen, Vol. 11, No. 3.

Sukasih, Sri, dkk. 2015. "Literasi Media Berbasis Pendidikan Karakter bagi Mahasiswa PGSD Unnes". Jurnal Penelitian Pendidikan, Vol. 32, No. 2.

Suwardana, Hendra. 2017. "Revolusi Industri 4.0 Berbasis Revolusi Mental", Jati Unik, Vol. 1, No. 2.

Tirto.id, Co-Working Space Bukan Sekadar Tempat Kerja, (Online), (https://tirto.id/, accessed 26 Desember 2019).

Tirto.id, Indeks SDM Bank Dunia 2018: Singapura Peringkat 1, Indonesia Ke-87, (Online), (https://tirto.id/, accessed 26 Desember 2019).

Voffice, Pengertian Co-Working Space, (Online), (http://voffice.co.id/, accessed 26 December 2019).

Witro, Doli, 2018, "Problematika Hoax di Media Sosial: Telaah Pesan Tabayyun dalam Surat Al-Hujurat/49: 6", Proceedings of the 3rd BUAF (Borneo Undergraduate Academic Forum), Institut Agama Islam Negeri (IAIN) Palangkaraya, Kalimantan Tengah, Indonesia, 17-19 Oktober.

Witro, Doli, 2020, "Urgency Rijalul Posting in Preventing Hoax: Quranic Perspective", Islamic Communication Journal, 


\section{Vol. 5, No. 1.}

Witro, Doli, Berlian Arista Putri, Luqyana Azmiya Putri, and Vegia Oviensy, 2020, "Role of the Family in Formation of Children Characters Based Moral Knowing, Moral Feeling, and Moral Action", Tunas Cendekia: Jurnal Program Studi Pendidikan Islam Anak Usia Dini, Vol. 3, No. 1.

Witro, Doli, Luqyana Azmiya Putri, and Vegia Oviensy, 2019, "Kontribusi Media Sosial Terhadap Produktivitas Karyawan Generasi Milenial PT Perkebunan Nusantara VI Kayu Aro", Jurnal Ekonomi \& Bisnis, Vol. 18, No. 2.

Witro, Doli. 2019. "Islamic Religious Education in the Family to Strengthen National Resilience of Surah At-Tahrim Verse 6 Perspective". Al-Muaddib: Jurnal IImu-IImu Sosial dan Keislaman, Vol. 4, No. 2.

Yustikasari, dan Lukiati Komala. 2017. "Literasi Media pada Anak (Studi tentang Literasi Media pada Anak dalam Membangun Pemahaman tentang Penggunaan Media)". Seminar Nasional Bahasa, Sastra, dan Budaya, Vol. 1, No. 1.

Yusuf, Muhamad, Doli Witro, Rahmi Diana, Tomi Apra Santosa, Annisa 'Alwiyah Alfikri, and Jalwis, 2020, "Digital Parenting to Children Using the Internet". Pedagogik Journal of Islamic Elementary School, Vol. 3, No. 1. 